\title{
Pemetaan Zona Korosivitas Tanah Berdasarkan Nilai Chargeability Menggunakan Metode Time Domain Induced Polarization Konfigurasi Dipole-Dipole Studi Kasus PT. IPMOMI
}

\author{
Kiki Kartika Dewi, Widya Utama dan Juan Pandu Gya Nur Rochman \\ Departemen Teknik Geofisika, Fakultas Teknik Sipil dan Perencanaan, Institut Teknologi Sepuluh Nopember (ITS) \\ Jl. Arief Rahman Hakim, Surabaya 60111, Indonesia \\ e-mail: djuan.rochman@gmail.com
}

\begin{abstract}
Abstrak-Pipa bawah tanah menjadi elemen yang sangat penting dalam dunia industri salah satunya untuk mengalirkan fluida. Masalah serius yang sering dihadapi adalah kontak antara pipa dengan tanah dan lingkungan yang dapat menimbulkan korosi. Maka dari itu, dibutuhkan penanganan khusus agar tidak terjadi kerusakan dan ketidakstabilan tanah. Salah satu upaya awal untuk menangani hal tersebut adalah dengan melakukan pemetaan zona korosi bawah permukaan yang pada penelitian Tugas Akhir kali ini dilakukan dengan metode Time Domain Induced Polarization dengan konfigurasi dipole-dipole sebanyak 5 lintasan. Respon chargeability terhadap korosivitas tanah pada lokasi penelitian secara rata-rata menunjukkan hubungan yang berbanding lurus, semakin tinggi nilai chargeability maka semakin tinggi tingkat korosivitas tanah. Zona korosivitas tanah sangat ringan hingga sedang menyebar pada kedalaman 0-4.72 meter sedangkan zona korosivitas tanah tinggi hingga sangat tinggi berada pada kedalaman 2.72-4.72 meter.
\end{abstract}

Kata Kunci-chargeability, induced polarization, korosivitas tanah, PT.IPMOMI

\section{PENDAHULUAN}

S ISTEM perpipaan cenderung menjadi perhatian dalam dunia industri. Sistem perpipaan ini dianggap memiliki tingkat integritas yang tinggi serta lebih efektif dan efisien dibanding sistem transportasi lain. Kegiatan industri dan infrastruktur sering kali menggunakan pipa yang ditanam di bawah permukaan tanah, salah satu contohnya adalah PT.IPMOMI yang memiliki pipa bawah tanah yang berfungsi untuk mengalirkan fluida berupa air laut sebagai bahan utama produksi uap. Dalam sistem perpipaan ini kebanyakan jenis bahan pipa yang digunakan adalah jenis logam (Norin, 1998; Beaver \& Thompson, 2006), disamping keunggulannya logam juga mempunyai banyak kelemahan jika di bandingkan dengan unsur unsur lain dikarenakan sifat logam yang mudah terkorosi. Korosi adalah perusakan atau penurunan mutu dari material akibat bereaksi dengan lingkungan (Fontana, 1986). Korosivitas tanah merupakan masalah multi disiplin yang memiliki dampak terhadap keselamatan lingkungan dan struktural.
Korosi yang terjadi selanjutnya akan menyebabkan ketidakstabilan dan kerusakan tanah. Selama berjalannya waktu korosi menjadi masalah yang serius. Hal tersebut mulai diperhatikan mulai dari pencegahan dan penanganannya. Disebutkan oleh Koch et. al. (2002) bahwa di Amerika biaya yang dikeluarkan untuk penanganan korosi pada perusahaan air minum mencapai US\$ 36 billion, sedangkan pada sector gas mencapai US\$ 5 billion. Karena bersifat korosif atau merusak maka perlu dilakukan pencegahan dengan melakukan beberapa perlakuan pada daerah yang memiliki pipa logam di bawah permukaan, salah satunya adalah dengan melakukan pemetaan zona korosivitas tanah.

Metode geofisika yang biasa digunakan untuk melakukan zonasi korosivitas tanah adalah metode resistivitas. Metode geolistrik yang lain seperti Induced Polarization masih jarang digunakan dalam permasalahan ini. Maka dari itu penulis ingin mengetahui bagaimana respon nilai chargeability yang diperoleh dari pengukuran metode Induced Polarization terhadap tingkat korosivitas tanah. Prinsip dasar metode Induced Polarization adalah dengan mengalirkan arus listrik kedalam bumi kemudian mengamati beda potensial yang terjadi setelah arus listrik dihentikan. Konfigurasi dipole-dipole yang digunakan diyakini efektif untuk memetakan zona korosivitas tanah secara lateral. Tujuan dari penelitian ini adalah untuk mengetahui respon nilai chargeability terhadap korosivitas tanah. Serta mengetahui sebaran zona korosivitas tanah berdasarkan nilai chargeability pada daerah penelitian.

\section{METODOLOGI}

Alur pengerjaan penelitian dapat dilihat pada Gambar 1. 


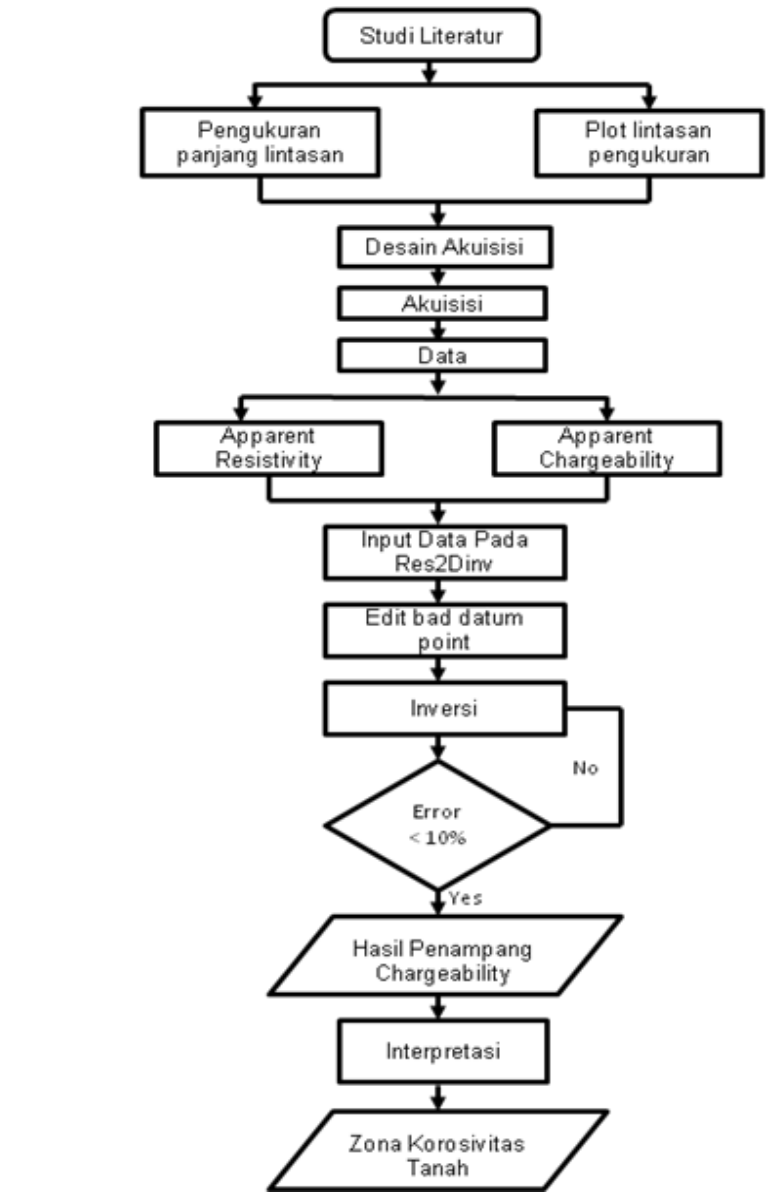

Gambar 1. Diagram Alir Penelitian

Akuisisi data dengan target kedalaman 5 meter dilakukan dengan 2 lintasan sepanjang 72 meter, 2 lintasan sepanjang 32 meter dan satu lintasan sepanjang 54 meter. Berikut ini adalah desain akuisisi pengukuran.

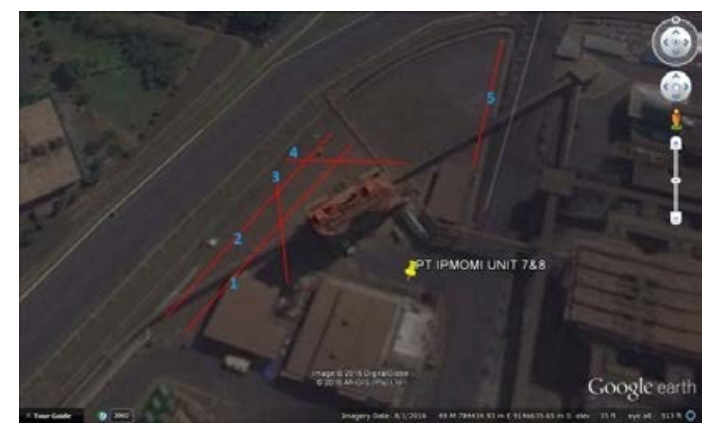

Gambar 2. Desain akuisisi pengukuran metode IP

Pengukuran metode Induced Polarization dilakukan selama 7 hari, jenis tanah pada lokasi penelitian meurupakan tanah urukan. Setelah diperoleh data dilakukan perhitungan apparent resistivity dan apparent chargeability untuk selanjutnya menjadi input pengolahan pada software Res2Dinv.

\section{HASIL DAN DISKUSI}

Hasil inversi resistivitas dan chargeability menunjukkan bahwa litologi daerah penelitian merupakan alluvium dengan resistivitas sebesar 3-333 ohm.m dan chargeability sebesar 0.11.8 msec. Hasil inversi menunjukkan bahwa mayoritas tingkat korosivitas tanah daerah penelitian pada kedalaman 0-2 meter berada pada tingkat yang sangat ringan. Pada kedalaman 2-3 meter dari permukaan mulai menunjukkan tingkat korosivitas yang lebih bervariasi mulai dari sedang hingga sangat tinggi.

Sifat korosivitas tanah telah banyak diketahui berdasarkan nilai resistivitas namun masih sangat jarang dihubungkan dengan nilai chargeability. Maka dari itu belum ada acuan pasti mengenai hubungan antara korosivitas dan chargeability. Sehingga penulis mencoba menghubungkan antara nilai ketiganya berdasarkan zonasi yang sama. Untuk mengetahui respon nilai chargeability terhadap korosivitas tanah khususnya pada daerah penelitian. Berikut ini adalah Tabel 1 yang menunjukkan hubungan antara tingkat korosivitas tanah, reesistivits dan chargeability.

Tabel 1.

Hubungan antara tingkat korosivitas tanah, reesistivits dan chargeability

\begin{tabular}{lll}
\hline \hline Tingkat korosivitas & Resistivitas & Chargeability \\
\hline Sangat Tinggi & $0.98-6.33$ & 0.7979 \\
Tinggi & $7.33-19.81$ & 0.5080 \\
Sedang & $20.25-49.81$ & 0.2513 \\
Ringan & $50.03-99.68$ & 0.1709 \\
Sangat Ringan & $100.01-1882.4$ & 0.1474 \\
\hline \hline
\end{tabular}

Nilai chargeability berbanding lurus dengan tingkat korosivitas tanah hal tersebut disebabkan ketika suatu tanah bersifat lebih konduktif daripada lingkungannya maka nilai chargeabilitynya cenderung lebih tinggi. (Alaminiokuma, 2010) mengatakan bahwa tanah yang konduktif menyebabkan adanya jalur yang menghubungkan antara anoda dan katoda pada proses terjadinya korosi. Hal tersebut berarti semakin konduktif suatu media maka semakin membuka jalan untuk terjadinya korosi. Persebaran nilai chargeability dapat dilihat pada Gambar 3 berikut ini

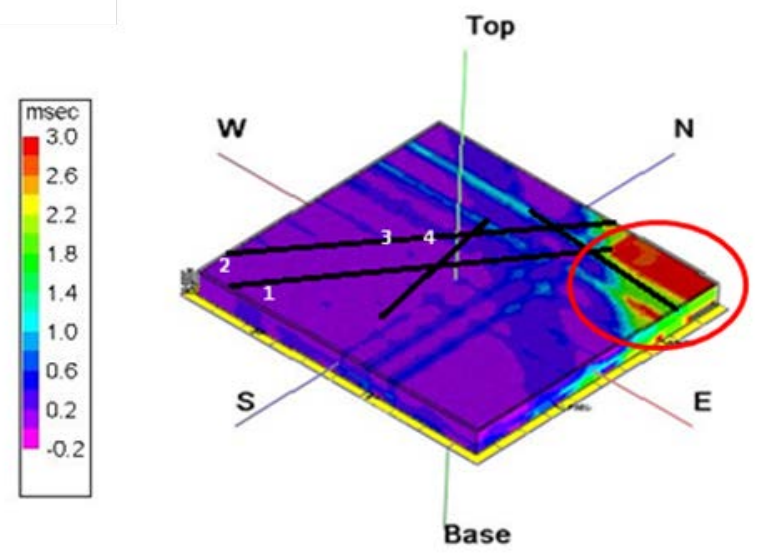

Gambar 3. Penampang 3D Chargeability 
Zona korosivitas tanah sangat ringan hingga sedang menyebar pada kedalaman 0-4.72 meter dengan rentang nilai chargeabiity $0.1474-0.2513$ msec. Sedangkan zona korosivitas tanah tinggi hingga sangat tinggi berada pada kedalaman 2.72-4.72 meter dengan rentang nilai chargeability 0.5080-0.7979 msec. Lingkaran merah menunjukkan zona korosivitas sangat tinggi, respon yang sama ditunjukkan pada penampang 2D native potential berikut ini.

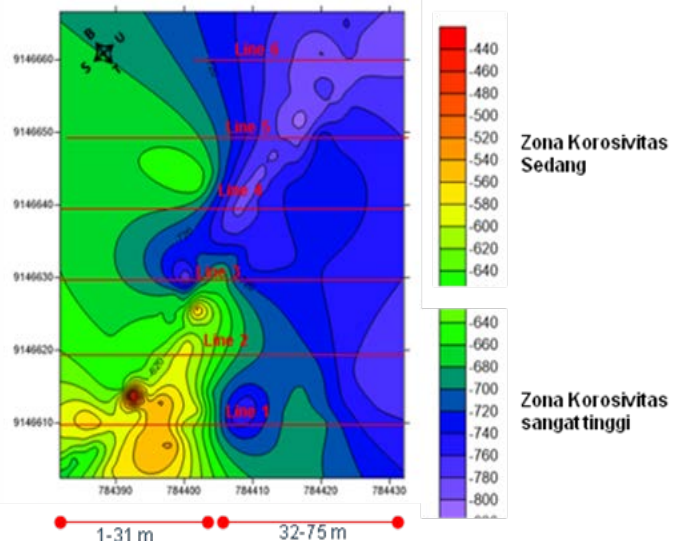

Gambar 4. Penampang 2D Native Potential daerah penelitian (Amalia, 2017)

Zona korosivitas tanah secara lateral seperti yang ditunjukkan pada gambar 3 dan 4 menunjukkan bahwa pada sisi timur laut daerah penelitian menunjukkan tingkat korosivitas yang sangat tinggi hal tersebut ditunjukkan pula pada penampang 2D native potensial bahwa pada sisi timur laut daerah penelitian memiliki range native potensial -700 hingga $-820 \mathrm{mV}$ yang mengindikasi tingkat korosivitas yang sangat tinggi yaitu $<-600 \mathrm{mV}$.

\section{KESIMPULAN}

Dari penelitian yang dilakukan dapat disimpulkan bahwa respon chargeability terhadap korosivitas tanah pada lokasi penelitian secara rata-rata menunjukkan hubungan yang berbanding lurus, semakin tinggi nilai chargeability maka semakin tinggi tingkat korosivitas tanah. Zona korosivitas tanah sangat ringan hingga sedang menyebar pada kedalaman 0-4.72 meter sedangkan zona korosivitas tanah tinggi hingga sangat tinggi berada pada kedalaman 2.72-4.72 meter

\section{DAFTAR PUSTAKA}

[1] Alaminiokuma, G. I.*, Osokpor, J.*, Emudianughe, J. E.* and Warmate, T. 2010. Delineation of Soil Corrosivity Regimes Along Petroleum Pipeline Routes in the Geomorphic Zones of the Niger Delta using 2D Resistivity Tomography

[2] Beavers, J.A., Thompson, N.G. 2006. External Corrosion of Oil and Natural Gas Pipeline. ASM Handbook Volume 13C, Corrosion: Environments and Industries. ASM International.
[3] Cramer S.D. and Jr. Covino B.S. 2003. ASM Handbook Volume 13A Corrosion: Fundamentals, Testing, and Protection, ASM International.

[4] Fontana, Mars.G 1986, “Corrosion Engineering”, 3rd Edition, Mc GrawHill Book Company, Singapore.

[5] Keller, G. V. dan Frischknecht, F. C. 1966. Electrical Methods in Geophysical Prospecting. In international series of monographs in Electromagnetic Waves, 10, eds. A.L. Cullen, V. A. Fock, and J. R. Wait. Oxford: Pergammon Press.

[6] Koch, G., Brongers, M.P.H., Thompson, N.G., Virmani, Y.P., Payer, J.H. 2002. Corrosion Costs and Preventative Strategies in the United States. Publication No. FHWA-RD-01-156. U.S. Federal Highway Administration Washington, U.S.A.

[7] Loke, M.H. 1999. Electrical Imaging Surveys For Environmental And Enginering Studies. Malaysia. Penang.

[8] Norin, M. 1998. Groundwater and Soil Properties in an urban Environment and their effects on the Corrosion of Soil Buried Constructions of Carbon, Steel, and Zinc. Department of Geology, Chalmers University of Technology. Goteborg.

[9] Puslitbang Metalurgi-LIPI, 1987. Korosi dan Penanggulangannya.

[10] Reynolds, J.M., 1997. An Introduction to Applied and Environmental Geophysics. New York:John Willey and Sons.

[11] Saputro Bayu, dkk. (2010). Panduan Praktikum Geolistrik. Yogyakarta: Prodi Teknik Geofisika. Fakultas Teknologi Mineral. UPN Yogyakarta.

[12] Telford, W.M., L.P. Geldart, , R.E. Sheriff, dan D.A. Keys. 1982. Applied Geophysic. London : Cambridge University Press 